\title{
Our Right to Share, Their Right to Know: An Analysis of Public Interest Defense to Defamation
}

\author{
Kezia Ezekiel* \\ University of Indonesia, Indonesia
}

\begin{abstract}
The defamation reports have increased and shifted under online-based technology through social media. This study considered the defamation issue in Indonesia that alleged Richard Lee, a doctor who shared a beneficial publication through social media about the dangerous skincare product. Richard's audience believed that his content helped them know the hidden truth behind skincare products available in the market. Consequently, the public questioned whether he was liable because he was regarded to share helpful information under the public interest. This study aimed to analyze Indonesia's defamation laws, especially in public interest defense under Article 310(3) of the Indonesian Criminal Code. However, the interpretation for public interest as a crime abolition is unclear, resulting in various courts' decisions that lead to criminalizing internet users. This study used legal research with statutory and comparative approaches. It examined legal norms and practices in Indonesia and compared those in the United Kingdom, Canada, and New Zealand. These three countries adapted defamation law to develop cases, including those alleged defamations for the public interest. While the freedom of expression is enshrined in the constitution, its practice has contradicted defamation provisions outlined in derivative regulations. By comparison, these three countries have precise boundaries and public interest defense is explicit. Those countries have specific rules and lists that needed to be fulfilled for those who use public interest defense. The lists based on previous precedents show how they learn and adapt to the development of public interest defense in many cases. This study concluded that Indonesia does not have specific standards or rules to determine cases categorized as the public interest.
\end{abstract}

KEYWORDS: Public Interest Defense, Online Defamation, Freedom of Expression.

Copyright $(2021$ by Author(s)

This work is licensed under a Creative Commons Attribution-ShareAlike 4.0 International License. All writings published in this journal are personal views of the authors and do not represent the views of this journal and the author's affiliated institutions.

HOW TO CITE:

Ezekiel, Kezia, "Our Right to Share, Their Right to Know: An Analysis of Public Interest Defense to Defamation" (2021) 8:2 Lentera Hukum 241-266. DOI: <https://doi.org/10.19184/ejlh. v8i2.23833>.

Submitted: 10/04/2021 Reviewed: 15/04/2021 Revised: 09/07/2021 Accepted: 10/07/2021

\footnotetext{
* Corresponding author's e-mail: keziaezekiel@yahoo.com
} 


\section{INTRODUCTION}

Freedom of expression is part of fundamental rights and becomes the foundation for a democratic society. It is also protected in international law. ${ }^{1}$ Freedom of expression ensures everyone conveys, seeks, receives, processes, and distributes various information to express opinions or ideas through various methods and media deemed appropriate. ${ }^{2}$ In international human rights, freedom of expression, speech, and opinion is adopted in the international instruments that apply to all state parties ratifying them. ${ }^{3}$ For instance, in 1948, the United Nations General Assembly issued the Universal Declaration of Human Rights (UDHR). As a member of the United Nations, Indonesia must comply with the declaration. In 1966, the United Nations also issued the International Covenant on Civil and Political Rights (ICCPR) to strengthen the protection of human rights, ratified by Indonesia in 2005. Article 19 of the UDHR and Article 19 of the ICCPR stated that the state party must protect its people's freedom of expression. ${ }^{4}$ Subsequently, the Indonesian government has to ensure that all laws are consistent with the freedom of expression, including its procedural law, which is the law that establishes the set of rules and the methods used to ensure a fair process in the enforcement of legal rights of the subjects of law. Procedural law is limited to rules used in the court and the process of investigation and collection of evidence. Freedom of expression, however, to some extend may contradict other protected rights. The right to speak must be burdened with an assurance what he/she spreads is factual and is vital for the public. The possibility of such contradiction created an urgency for the government to set some boundaries for such freedom. Thus, the laws of defamation are established.

1 Emily Howie, "Protecting the Human Right to Freedom of Expression in International Law” (2018) International Journal of Speech-Language Pathology 20:1 at 12.

2 Anggara, et. al., "Menimbang Ulang Pasal 27 ayat (3) UU ITE dalam Putusan Pengadilan: Pertimbangan Putusan Pengadilan Terkait Penggunaan Pasal 27 ayat (3) UU No 11 Tahun 2008 tentang Informasi dan Transaksi Elektronik di Indonesia" (2016) Institute for Criminal Justice Reform at 2.

3 Nadiyah Munisah Hamelia, "The Implementation of the International Covenant on Civil and Political Right (ICCPR) as an International Regime in Indonesia During the Joko Widodo Era (2014-2019)" (2020) Mediasi: Journal of International Relation at 4.

4 Article 19 of UDHR. 
While social media has been commonly used, reports of defamation are increasingly being made. The UDHR and the ICCPR guarantee the freedom of expression, both verbal and by other communication media, including through the internet. ${ }^{5}$ The Human Rights Council emphasizes that everyone should enjoy the same rights online or offline. ${ }^{6}$ Therefore, Indonesia enacted the Electronic Information and Transactions Law 11/2008 (ITE Law) to comply with both international instruments that aimed to protect freedom of expression in the internet regime that regulates online defamation. However, the recent case has attracted public attention after Richard Lee, a medical doctor, posted content on his social media about skin health. ${ }^{7}$ A celebrity Kartika Putri reported him under the defamation issue. ${ }^{8}$ The report was based on Lee's TikTok content that exposed essential facts to the public regarding the skincare composition suspected of being dangerous where Kartika was the brand ambassador. These facts revealed by laboratory test results were not generally exposed because they require special paid tests. ${ }^{9}$ Despite the unclear legal process, the big question arises, is this defamation report valid if what the doctor stated was factual and helpful?

In Indonesia, previous studies indicate that public interest is a crime abolition. The first study linked the issue to the theory of crime abolition, which was also supported by precedents. ${ }^{10}$ Article 310(3) has eliminated the element of action against the law from perpetrators' actions committing defamation explicitly for the greater good of public interest or defend

5 Anak Agung Saraswati, "The Need to Protect Freedom of Expression on the Internet through a Human Rights-Based in Indonesia" (2019) Asian Journal of Legal Studies 2:1 at 57.

6 Kamshad Mohsin and Zainab Zaya Khan, "Right to Privacy in Digital Era" (2020) SSRN at 4.

7 Baharudin Al Farisi, Alasan Kartika Putri Tetap Laporkan Richard Lee ke Polisi walau Sudah Minta Maaf (2021), online: <https://www.kompas.com/hype/read/ 2021/03/01/071730266/alasan-kartika-putri-tetap-laporkan-richard-lee-ke-polisiwalau-sudah-minta?page $=$ all $>$.

8 Ibid.

9 Ibid.

10 Putra Akay, "Pasal 310 ayat (3) Kitab Undang-Undang Hukum Pidana Sebagai Suatu Alasan Penghapus Pidana Khusus” (2019) Lex Crimen 8:8 at 73. 
themselves. ${ }^{11}$ However, most previous studies never explained such acts categorized as defamation under public interest. A recent study on the defamation act in journalism mentioned that a person's actions are not categorized as defamation as long as to defend the personal or public interest because of revealing the truth. ${ }^{12}$ This idea is underrepresented because the study never mentioned doctrines nor gave more details on the definition and standard of truth. Other civil law countries in Asia, which also believe in public interest defense to defamation act, like South Korea and Japan, stated that one of the criteria of the public interest defense is that alleged defamation must be factual. For instance, Korean Criminal Act (byeongbeop) in Article 310 states that alleged facts that are true and solely for the public interest shall not be punishable. ${ }^{13}$ Also, Article 230-2 of the Japan Penal Code states that elements of immunity from criminal liability in defamation law are the stated facts related to matters of public interest, statements are made for the benefit of the public, and the stated facts are facts-true. ${ }^{14}$ Therefore, the regulatory regime of the same issue is different from the common practice.

Since information technology and social media have changed human civilization globally, Indonesia created a defamation clause in ITE Law. ${ }^{15}$ Most previous studies emphasize the obscurity of the defamation clause in ITE Law. Those studies believe that the article on defamation still requires countless interpretations, ${ }^{16}$ which leads to injustice despite restricting the

11 Ibid.

12 Sitti Aisah Abdullah, et al., "The Legal Protection for Journalism of Citizen in the Spread Corona Virus Disease 2019 (COVID-19)" (2020) Scholars International Journal of Law, Crime and Justice at 435.

13 Kyung Sin Park and Jong-Sung You, "Criminal Prosecutions for Defamation and Insult in South Korea with a Leflarian Study in Election Contexts" (2017) University of Pennsylvania Asian Law Review 12:4 at 465.

${ }^{14}$ Jun Shimizu, "Defamation and Privacy Law in Japan - from a Comparative Perspective" (2020) Comparative Privacy and Defamation at 417.

15 Rafika Nur, et al., "Insult and Defamation through Information Technology: Indonesia Perspective" (2020) International Journal of Emerging Technologies 11:4 at 373.

16 Anggara, et al., supra note 2, at 12. 
freedom of expression. ${ }^{17}$ While the discussion will analyze it is regarded as abuse, further elaboration remains vital by highlighting some regulatory issues and practices. Furthermore, there are no laws, regulations, decrees, or guidances that specify the meaning and criteria of defamation. It distorts the judges in assessing whether an action constitutes defamation. ${ }^{18}$

This study is not necessarily in disagreement with the conclusions reached by those writers, but its starting point is different. This study aimed to identify public interest's blur as a defense to defamation in Indonesian criminal law. Also, it analyzed whether a person can be liable if the act of alleged defamation is fulfilling the public interest, corresponding to Richard Lee's case. It compares rules and practices regarding public interest defense in the United Kingdom, Canada, and New Zealand because they have several similarities and may contribute to the legal discourse in the Indonesian context. The landmark cases related to public interest defense to defamation in those countries associated with journalism include Reynolds $v$ Times Newspaper Ltd and Others. Many defamation cases have been considered a crime in Indonesia. On the other hand, also related to journalism, such as an act of defamation to Tommy Winata by Bambang Harymurti (Tempo $)^{19}$ to Soemadi Wonohito by President Director of Harian Kedaulatan Rakyat, ${ }^{20}$ to the member of Regional House of Representatives of Deli Serdang by Ramses Siregar (Panji Demokrasi). ${ }^{21}$ In Indonesia, the definition of journalism has expanded in which citizen journalism may be interpreted as a form of journalism produced by nonprofessionals that may take the form of text, image, video, and audio. ${ }^{22}$ What Richard Lee published in TikTok is construed as citizen journalism.

17 Muhammad Ardiansyah Arifin, et al., "Indonesia Abuse of Defamation Clause in Article 27 Section (3) of Electronic Information and Transaction Law" (2020) South East Asia Journal of Contemporary Business, Economics and Law 23:1 at 26.

18 Anggara et al., supra note 2, at 12.

19 Margiyono, "Seri Reformasi Kebijakan Media Seri II Kasus Pencemaran Nama" (2010) Aji Indonesia at 71.

${ }^{20}$ Margiyono, supra note 17 , at 85

21 Ibid at 117.

${ }^{22}$ Rajab Ritonga and Iswandi Syahputra, "Citizen Journalism and Public Participation in the Era of New Media in Indonesia: From Street to Tweet" (2019) Media and Communication $7: 3$ at 79. 
The United Kingdom, Canada, and New Zealand have an extensive definition of journalism, so that citizen journalism is included under the public interest defense.

This study is based on two main questions. First, how does Indonesia's defamation law consider public interest as a criminal defense? Second, how do the United Kingdom, Canada, and New Zealand regulate their public interest defense compared to Indonesia? Then, this study is divided into three parts. The first part provides a brief review of defamation laws in Indonesia. The second part examines public interest as a crime abolition for defamation. The third part provides a comparative study on Indonesia's public interest defense in defamation law against those regulated and practiced in the United Kingdom, Canada, and New Zealand.

\section{METHODS}

Based on the background, this study used legal research with statutory and comparative approaches. ${ }^{23}$ It examined legal norms and practices in Indonesia and compared those in the United Kingdom, Canada, and New Zealand. It is a descriptive study in obtaining a complete analysis and conclusion regarding the issue. Data collection used secondary data, which included a literature study. ${ }^{24}$ The literature study was carried out by collecting several legal documents, comprising primary, secondary, and tertiary legal documents. Primary legal documents were binding laws and regulations. Secondary legal documents were books, journal articles, doctrine, and web pages. Tertiary legal documents were in the form of a law dictionary.

23 Sri Mamudji, et, al., Metode Penelitian dan Penulisan Hukum, (Jakarta: Badan Penerbit Fakultas Hukum Universitas Indonesia, 2005) at 9-11.

24 Soerjono Soekanto and Sri Mamudji, Peranan dan Penggunaan Kepustakaan di dalam Penelitian Hukum, (Jakarta: Pusat Dokumentasi UI, 1979) at 18. 


\section{DEFAMATION IN INDONESIA'S CRIMINAL LAWS}

Defamation in Indonesia is regulated, both in criminal law and civil law. In the Indonesian Civil Code, defamation is outlined from Articles 1372 to 1380 on compensation for losses and restoration of honor and good name. This arrangement shows that the Indonesian Civil Code categorized defamation as a tort. ${ }^{25}$ This is reasonable since it fulfilled the four qualifications for tort according to the doctrines. First, it is contrary to the actor's legal obligations. Second, it is contrary to the subjective rights of others. Third, it is contrary to decency. Lastly, it is contrary to propriety, thoroughness, and prudence. ${ }^{26}$ Anyone who feels their right is violated can file a compensation claim. ${ }^{27}$ On the other hand, in the Indonesian Criminal Code, defamation can be made in writing and/or verbal. ${ }^{28}$ It is arranged from Articles 310 to 320. Given that more than 30\% of Indonesia's population are active internet users, ${ }^{29}$ policymakers subsequently regulate defamation committed on the internet. Then, the ITE law was enacted in $2008,{ }^{30}$ in which the clause on defamation was included in Article 27(3). The clause on defamation arranged criminal sanctions in Article 45(1). Indonesia's people tend to proceed the defamation using both laws. Unlike common law countries that did not criminalize the defamation act. However, regulation of defamation in Indonesian criminal law seems problematic. $^{31}$

25 Indonesian Civil Code, art 1372.

26 Rosa Agustina, Perbuatan Melawan Hukum, (Jakarta: Penerbit Pasca Sarjana FH Universitas Indonesia, 2003) at 53.

27 Eti Mul Erowati. "Compensation of defamation in Indonesia" (2019) 358 3rd International Conference on Globalization of Law and Local Wisdom (ICGLOW 2019) at 335 .

28 Aceto, Bonner, and Cole PC, The five requisite elements of a defamation lawsuit? (2017), online: <http://www.acetolegal.com/Articles/The-five-requisite-elementsof-a-defamation-lawsuit.shtml>.

29 Anggara, et al., supra note 2 at 1.

30 Law 11, Electronic Information and Transaction, 2008, art 27(3).

31 R. Herlambang Perdana Wiratraman, "New Media and Human Rights: The Legal Battle of Freedom of Expression in Indonesia" (2010) 11 ${ }^{\text {th }}$ Annual Student Human Rights Law Conference Nottingham University at 2. 


\section{A. Defamation in the Indonesian Criminal Code}

In the Indonesian Criminal Code, defamation can occur in five forms. It consists of defamation, a deliberate attack on someone's honor or good name, by publicly accusing them of something, verbally (smaad), or by writing (smaadschrift). ${ }^{32}$ It is also slander (laster), ${ }^{33}$ humiliation, ${ }^{34}$ false complaint (lasterlijke aanklacht) or an act of slander by submitting a complaint to the authorities, ${ }^{35}$ and false accusation, an act of creating false suspicion against someone by saying that they have committed a criminal act. $^{36}$ This study's dominant discussion relies on defamation and slander, regulated in Articles 310 and 311 of the Indonesian Criminal Code.

\section{Defamation}

Defamation is outlined in Article 310(1) of the Indonesian Criminal Code, which states as follows:

"The person who intentionally harms someone's honor or reputation by charging him with an inevitable fact, with the apparent intent to give publicity thereof, shall, being guilty of slander, be punished by a maximum imprisonment of nine months or a maximum fine of three hundred Rupiahs."

Article 310(2) regulated the similar to the above, but it emphasizes the act of defamation done by writings. It states that if this occurs through writings or portraits disseminated, openly demonstrated, or put up, the principal shall, being guilty of libel, be punished with a maximum imprisonment of one year and four months or a maximum fine of three hundred Rupiahs.

32 Reydi Vridell Awawangi, "Pencemaran Nama Baik dalam KUHP dan Menurut UU No 11 Tahun 2008 tentang Informasi dan Transaksi Eletronik" (2014) Lex Crimen 3:4 at 114.

33 Ibid at 115.

34 Ibid.

35 Ibid at 117.

36 Raisa L. Saroinsong, "Pertanggung Jawaban terbadap Pelaku Tindak Pidana Pencemaran Nama Baik Berdasarkan Pasal 310 KUHP" (2017) Lex Privatum 5:7 at 162. 
Article 310(3) outlined an essential provision, which is a defense for defamation. This provision is considered as a crime abolition for defamation. Article 310(3) states that neither slander nor libel shall exist as far as the principal has acted in the general interest or necessary defense.

The Indonesian Criminal Code divides defamation into two kinds. First, paragraph (1) stated that verbal defamation and writings were stated in paragraph (2). Both kinds have the same elements that must be proven in alleging defamation, which comprises four elements. First, "the person." The person refers to every legal subject responsible according to the law for all their actions. Meaning that if they have fulfilled the offense elements, they can be punishable under the law. In this article, "the person" refers to natuurlijk persoon or a human being. This is because the Indonesian Criminal Code is still not familiar with legal entities (recht persoon) as a legal subject. Second, it "intentionally harms someone's honor or reputation." The word "intentionally" or "deliberate intent" in the concept of material criminal law is referred to as opzet or dolus. In Memorie van Toelichting (MvT), "deliberate intent" is the basis of wanting to commit a certain crime (de bewuste richting van den wil op een bepaald misdrijf). It requires willens en weten (will and know), where someone who commits an act on purpose must have the will (willen) to do the act and must recognize or understand (weten) that his action contains a violation of honor or good name other people. However, this intention does not require an animus injuriandi. It signifies a "deliberate intention to insult." The Indonesian Supreme Court through Decision No. 37 K/Kr/1957 dated December 21, 1957 , consistently stated animus injuriandi is not needed ${ }^{37}$. The act of harming or attacking (aanranden) in this article is not referring to a physical attack since the object of the attack is a sense or feeling of self-respect, honor (eer), and the good name (goedennaam) of people. ${ }^{38}$ Third, by charging with a certain fact. The formula for charging with a certain fact or

37 Fifink Praiseda Alviolita and Barda Nawawi Arief, "Kebijakan Formulasi tentang Perumusan Tindak Pidana Pencemaran Nama Baik dalam Pembahar an Hukum Pidana di Indonesia" (2019) Law Reform 15:1 at 134.

38 Dyah Rosiana Puspitasari, "Judicial Review of Criminal Defamation According to The Law of Electronic Information and Transaction: A Case Study of Flourence Saulina Sihombing" (2017) Yustisia 6:3 at 638. 
accusing something to the victim is closely related to a 'certain action' that the actor states as an act of the victim, which is not necessarily true and proven. ${ }^{39}$ Fourth, "the apparent intent to give publicity." The formula for "obvious intent" here is the same as intentionally, which has been explained previously. It does not need animus injuriandi. If the perpetrator willen en weten that by his actions, that particular fact will be known to the public, this element is fulfilled. ${ }^{40}$ However, it was alleged that the modern theory of objective criteria had superseded the ancient animus injuriandi concepts. The objective criteria theory would have the actor liable if he were aware that the impact of his deed would result in a specific effect on the victim. ${ }^{41}$

\section{Slander}

Slander is outlined in Article 311(1) of the Indonesian Criminal Code. It states that any person committing slander or libel in ease proof of the truth of the charged fact is permitted shall be guilty of calumny and be punished by a maximum imprisonment of four years (if he/she does not produce said proof and the charge has been made against his/her better judgment). While the other elements are the same with Article 310, Article 311 included one unique element, which is "if he does not produce said proof and the charge had been made against his better judgment." This element relates to Article 310. According to Article 310(3), neither slander nor libel shall exist as far as the principal has acted in the general interest or for necessary defense.

The actor cannot be subject to defamation as for the general interest or necessary defense. According to the Elucidation of Article 310 of the Indonesian Criminal Code as written by Soesilo, if the actor claims that defamation is done for public interest or is forced for self-defense, it cannot

39 Ahmad Sofian, Tafsir Pasal Pencemaran Nama Baik, online: <https://businesslaw.binus.ac.id/2017/12/28/tafsir-pasal-pencemaran-nama-baik/>.

40 Erwin Asmadi, "Rumusan Delik dan Pemidanaan Bagi Tindak Pidana Pencemaran Nama Baik di Media Sosial' (2021) Delegalata 6:1 at 21.

41 Nono Anwar Makarim, "Press Freedom in Indonesia: A Case of Draconian Laws, Statutory Misinterpretation, but still one of the Freest in Southeast Asia" (2010) Journal of Civil Law Studies 3:1 at 140. 
prove it before the judge. In the case examination, it is proven that what the actor is accused of is not valid. The actor is not blamed for defamation but slander subject to Article 311 of the Indonesian Criminal Code. ${ }^{42}$

\section{B. Defamation in Indonesia According to ITE Law}

As mentioned before, defamation in Indonesian ITE Law is included in Article 27(3), which states that any person who knowingly and without authority distributes and/or transmits and/or causes to be accessible Electronic Information and/or Electronic Documents with contents of affronts and/or defamation. The term affronts and/or defamation shows that ITE Law distinguishes affront and defamation. Many parties showed objection to this provision, Narliswandi Pilian in 2008 and Eddy Cahyono in 2009. In Constitutional Court's Decision No. 50/PUU-VI/2008 on Judicial Review of Law 11/2008 against the 1945 Constitution $^{43}$, the court stood to its belief that Article 27(3) of ITE Law does not conflict with the rights of the citizens, freedom of expression, and the principle of the rule of law. ${ }^{44}$ Thus, despite its unclearness, this provision still stands. Based on Constitutional Court's Decision No. 50/PUU-VI/2008, the definition of affront and defamation in ITE Law Law refers to Articles 310 and 311 of the Indonesian Criminal Code. ${ }^{45}$ It results in considerable confusion. First, in the English translation of the Indonesian Criminal Code, Articles 310 and 311 both defined as slander. ${ }^{46}$

Furthermore, R. Soesilo explained that Article 311 would be applied if the actor is incapable of proving that said defamation is done to protect the public interest or defend himself based on Article 310(3). ${ }^{47}$ The question is, which definition categorized as "an affront and/or" based on ITE Law?

42 R. Soesilo, Kitab Undang-Undang Hukum Pidana (KUHP): Serta KomentarKomentarnya Lengkap Pasal Demi Pasal, (Bogor: Politeia, 1996) at 221.

43 Decision No 50/PUU-VI/2008 on Judicial Review of Law 11/2008 against the 1945 Constitution, the Constitutional Court of the Republic of Indonesia at 80.

44 Rafika, supra note 10 at 374.

45 Ibid.

46 Indonesian Criminal Code English Translation, Art 310-311, online: <https:// www.wipo.int/edocs/lexdocs/laws/en/id/id039en.pdf>.

47 Soesilo, supra note 33 at 222. 
Second, while based on doctrines, the term of defamation is stated in Article 310 of the Indonesian Criminal Code, the term of affront is still vague. The act regulated in Article 311 of the Indonesian Criminal Code is slander or calumny, an entirely different act since it requires another element to be proved. This element, where the actor cannot prove the exception of liability for defamation according to Article 310(3), separates slander and the other forms of defamation. While affront or light affront is included in Article 315, which an entirely different act than the others. The original Dutch version of the Indonesian Criminal Code, or Wetboek van Strafrecht, also distinguish the meaning of defamation (smaad) ${ }^{48}$ slander (laster), ${ }^{49}$ and affront (belediging). ${ }^{50}$ ITE Law is not clear on the definition of "an affront and/or defamation," thus it results in various interpretations.

\section{PUBLIC INTEREST DEFENSE TO DEFAMATION REPORTS}

There have been many criminal defamation cases in Indonesia. The case of dr. Richard that recently ensued is different from the previous cases. He is an aesthetic doctor who owns an aesthetic clinic. He bought various skincare requested by his audience, tested them in an official laboratory, and showed his audience the result through a TikTok video. He mainly shows the dangerous composition according to him, especially mercury and hydroquinone. ${ }^{51}$ In one of his Tiktok videos, he reveals that a skincare brand named Helwa Beautycare has mercury and hydroquinone in its products. Kartika Putri, who is Helwa Beautycare's brand ambassador, felt attacked by dr. Richard's video seems to be vilifying Helwa Beautycare products. Many of the convicted of defamation have committed insults by using harsh words on social media, which the public can see without

48 Wetboek Van Strafrecht, art 310.

49 Ibid art 311.

50 Ibid art 315.

51 Tim, Tanggapan BPOM Terkait Perseteruan Richard Lee-Kartika Putri (2021) online: <https:/www.cnnindonesia.com/gaya-hidup/20210208205046-277-603874 /tanggapan-bpom-terkait-perseteruan-richard-lee-kartika-putri>. 
proving the elements of defamation articles in the ITE Law. ${ }^{52}$ Uniquely, dr. Richard did not express words that are generally considered an insult by the public. Furthermore, his content is scientifically proven by the laboratory and therefore does not resemble slander or libel. Richard was deemed helpful for many audiences that do not know the truth behind those skincare products. People, especially those who feel saved by said allegedly dangerous skincare products, started to question whether dr. Richard is liable for defamation. Also, can Richard defend with public interest defense?

Article 310(3) of the Indonesian Criminal Code regulated the limitation on the act of defamation. The actor would not be liable to protect the public interest or defend himself/herself. However, the definition of public interest and the necessary defense has never been explained neither in the Indonesian Criminal Code nor in the ITE Law. ${ }^{53}$ Sianturi stated that what is meant by "in the public interest" is that the actor is indeed clearly and emphatically accusing someone of something so that the public is alert to the "defiled" person. ${ }^{54}$ Hoge Raad (Supreme Court of the Netherlands), in its decision dated November 26, 1934, that "if the publication is for the public interest, then the actor must mention it sufficiently. By blaming said person indignantly, the public interest is being defended. ${ }^{55}$ Said defamation has to be done reasonably for the exception of public interest to prevail. Even if it is true that the act is carried out in the public interest, the use of harsh words will result in the actor being prosecuted for committing a light affront regulated in Article 315 of the Indonesian Criminal Code. ${ }^{56}$ Then again, laws do not have the definition of what is harsh. A particular word or even intonation may hurt some people, but other people may still consider these words polite. This subjectivity makes the public interest as a limitation on defamation deeds is difficult to succeed.

52 Anggara, et al., supra note 2 at 18.

3 Akay, supra note 9.

54 S. R. Sianturi, Tindak Pidana di KUHP Berikut Uraiannya, (Jakarta: Alumni AHMPTHM, 1983) at 562.

55 Akay, supra note 9.

56 Ibid. 
The definition of public interest cannot be segregated from the domination of public law. ${ }^{57}$ While defamation law tries to balance the right to freedom of expression and the right to protect reputation, one's right to protect reputation is easily sacrifice when the actor's freedom of expression sides to the public. Thus, the concept of public interest aims to protect the public above all; even one's right may have to be sacrificed. ${ }^{58}$ Various studies stated that in determining whether a subject matter of publication was in the public interest, the subject matter should be one inviting public attention. Otherwise, the public or a segment of the public has some substantial concern because it affects the welfare of citizens or one to which considerable public notoriety or controversy has attached..$^{59}$ This definition is likely to include science and arts to the environment, religion, and morality. It would also cover government affairs, the police, the military, and the secret service. ${ }^{60}$ Moreover, public interest must also consider several aspects, such as the seriousness of the allegation, the degree of public importance, and the urgency of the matter.

Richard's publication can help a group of people, namely local skincare users, specifically Helwa Beautycare's users. Based on the criteria above, what dr. Richard did protect these groups of people's health. However, dr. Richard has another burden of proof, whether these groups of people represent the public interest? This burden is essential to be answered since it shows that the degree of public importance is high. This burden of proof leads to another question, how do we determine the urgency and the degree of public importance? Moreover, the laws that do not regulate such criteria may result in a diverse decision between jurisdictions because it relies solely on the judges' opinion. In common law countries, this kind of blur will not be problematic since they can refer to courts' decisions. However, since Indonesia is a civil law country, it must establish a law or regulation legally binding on criteria that must be fulfilled to use a public interest defense.

57 M. Fauzi, "State, Public Interest, and Bankruptcy: The Case of Indonesia" (2018) South East Asia Journal of Contemporary Business, Economics, and Law 15:5 at 274.

58 Ibid.

59 Devesh Awmee, "With Great Power Comes Great Responsibility: An Analysis of the New Public Interest Defense to Defamation Claims" (2018) University of Wellington at 16.

60 Ibid. 
The First Amendment of the United States on freedom of speech spearheaded a "chilling effect." ${ }^{11}$ This term is used to describe the dissemination of information and comment on matters of public interest because of the risk of liability in damages or exposure to costly litigation. ${ }^{62}$ Thus, provoke uncertainty and fear among writers and journalists. While the chilling effect at first studied is based on journalism and the development of social media, this may impact social media influencers or content creators. ${ }^{63}$ The lack of clarity of the standards in determining defamation can be categorized as public interest silences people who intend to reveal 'hidden facts' that might harm society. Not only will it be dangerous to society, but it also will threaten people's right to speech. The original purpose of the defamation law, which was intended to balance freedom of speech and the right to protect reputation, was not achieved due to this lack of clarity. The difficulty of proving a public interest defense makes it appear that the defamation law protects the right to protect reputation more.

\section{A COMPARATIVE PERSPECTIVE ON PUBLIC INTEREST DEFENSE TO THE DEFAMATION CASE}

It is essential to compare and examine rules and practices in other countries that classified defamation as a tort. These countries use tort law to proceed with a defamation case. While Indonesian defamation law is different since criminal report for defamation is available in Indonesia, the concept of public interest defense is the same between tort law and criminal law. This section will examine public interest defense in the common law system by referring to the United Kingdom, Canada, and New Zealand. The subsequent analysis will compare it to the Indonesian context.

61 Judith Townend, "Freedom of Expression and the Chilling Effect" (2017) Routledge Companion to Media and Human Rights at 1.

${ }^{62}$ Ibid at 19.

${ }^{63}$ Townend, supra note 52 at 1. 


\section{A. Public Interest Defense Concept in the Common Law System}

There are occasions where the law permits one person to publish or share information without considering other's right to their reputation. ${ }^{64}$ The law permits this kind of occasion because the information is critical. Statements made on such occasions are described as privileged. The privilege concept is often used in common law countries, including England, Canada, and New Zealand. There are two main types of privilege, absolute privilege, and qualified privilege. Absolute privilege allows a person to say anything, even if they know that what they are saying is false or they say it with malicious intent. ${ }^{65}$ Occasions categorized as absolute privilege include statements made during judicial proceedings and parliamentary proceedings. Qualified privilege allows accessible communication in certain relationships without the risk of that action becoming defamation. Qualified privilege occurs on an occasion where the person communicating the statement has a legal, moral, or social duty to make it, and the recipient has a corresponding interest in receiving it, ${ }^{66}$ such as a reference for a job applicant, answering police inquiries, communications between teachers and parents, employers and employees, or traders and credit agencies. The qualified privileged must relate to the business at hand and cannot be abused to relay gossip. ${ }^{67}$ The privilege concept creates a neat limitation between action categorized as defamation and action released from defamation.

Based on various courts' decisions in England, it implied that public interest is considered an extension of qualified privilege. However, now the public defense is distinct and separate from existing forms of these privileges. ${ }^{68}$ It is a different form of defense composed of two elements. First, the subject matter of the publication must be in the public interest.

${ }^{64}$ Ursula Cheer, "Burrows and Cheer: Media Law in New Zealand" (2015) $7^{\text {th }}$ ed LexisNexis at 113.

${ }^{65}$ Ibid at 114.

66 Adam v Ward (1917) AC 309 (HL) at 334 per Lord Atkinson.

67 Legal Services Commission of South Australia, Qualified Privilege, online: $<$ https://lawhandbook.sa.gov.au/ch16s05s05.php\#: :text=The\%20defense\%20of\%20 qualified\%20privilege,corresponding\%20interest\%20in\%20receiving\%20it.>

68 Ruiteng Liu, "Innovation and Reform: Applying New Zealand's Public Interest Defense in Defamation to Social Media and Blogs" (2020) Victoria University of Wellington Legal Research Papers 21:7 at 5. 
Second, the communication must be responsible. The two elements are decided by a judge, where the defendant bears the burden of proof. ${ }^{69}$

\section{United Kingdom}

Public interest defense in the United Kingdom has gone through various decisions, evaluations, and analyses. Reynolds $v$ Times Nerwspaper Ltd and Others is a landmark defamation case because it brought fault, in the form of reasonableness, into the law. ${ }^{70}$ Reynolds, a politician, claimed that Times defamed by saying Reynolds was a liar and failed to publish his side of the events. The issue was whether an honest but mistaken news article about a politician was protected by qualified privilege. The House of Lord stated a defense by protecting the information of public concern and providing ten non-exhaustive factors that determined whether the standards of responsible journalism were met, which consists of, first, the seriousness of the allegation. The more serious the charge, the more the public is misinformed, and the individual is harmed if the allegation is not valid. Second, the nature of the information and the extent to which the subject matter is a matter of public concern. Third, the source of information. Some informants have no direct knowledge of the events. Some have their axes to grind or are being paid for their stories. Fourth, the steps are taken to verify the information. Fifth is the status of the information. The allegation may have already been the subject of an investigation that commands respect. Sixth is the urgency of the matter. News is often a perishable commodity. Seventh, whether a comment was sought from the plaintiff. He may have information others do not possess or have not disclosed. An approach to the plaintiff will not always be necessary. Eighth, whether the article contained the gist of the plaintiff's side of the story. Ninth, the tone of the article. A newspaper can raise queries or call for an investigation. It does not need to adopt allegations as statements of fact. Tenth, the circumstances of the publication, including the timing.

69 Andrew Kenyon, Comparative Defamation and Privacy Law (Cambridge: Cambridge University Press, 2016) at 58.

70 Hilary Young, "Reynolds v Times Nerwspaper Ltd and Others" in David Rolph, Landmark Cases in defamation Law (Oxford: Hart Publishing, 2019) at 215. 
This effect of this list is considered to be snare and an illusion for freedom of expression since it was not applied beyond investigative journalism ${ }^{71}$ and make it difficult for the journalist as a defendant to establish they published responsibly. ${ }^{72}$ This also can be troublesome for social media defendants.

In 2013, United Kingdom introduced the Defamation Act 2013, abolishing the Reynolds defense in favor of a different two-step test. First, the statement must be on a matter of public interest. Second, the defendant reasonably believed the statement was in the public interest. ${ }^{73}$ This Defamation Act 2013 confirms that an objective and subjective approach is undertaken. It recognizes the defendant's relationship to the publication, such as whether they were merely contributors or professional journalists. However, it does not clarify how reasonable journalism will be assessed ${ }^{74}$ to social media influencers or content creators on different platforms, such as Instagram, YouTube, and TikTok. Such social media defendants will face difficulties in trying to meet the defense requirements because the courts will treat such defendants as if they were professional journalists. ${ }^{75}$ While the United Kingdom has cleared the lists of public defense to have prevailed for journalists, it has not been explained how the lists will be used for social media defendants.

\section{Canada}

Canada had also adopted the two-stage public interest defense as Reynolds in Grant v Torstar Corp in 2009. ${ }^{76}$ Based on the Grant case, the defense was open to both mainstream media and non-media defendants. This has been followed by several cases, such as Casses $v$ Backer in 2012,77 which confirmed that the defense could be applied to non-media defendants. Even though Canadian Courts allow the availability for non-media

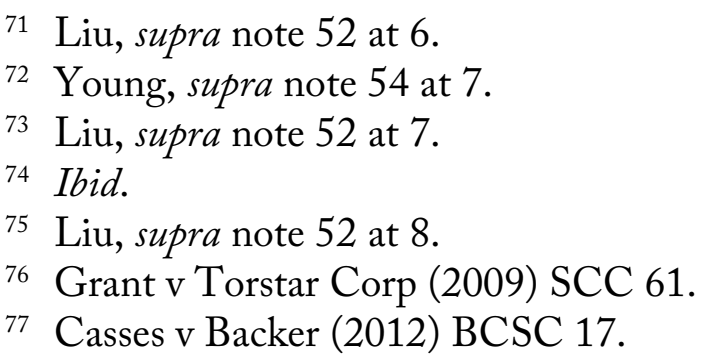


defendants, in reality, it is difficult to prove the public interest defense since the publication is believed to be not involved in "broad-based media." ${ }^{178}$ Moreover, the courts' decisions focused on the second of the two-stage public interest defense factors: the defendant reasonably believed the statement was in the public interest. In the second of the two-stage, the publisher or defendant must regard the seriousness of the allegation, the public importance, the urgency, the status and reliability of the source, whether the plaintiff's side of the story was sought and accurately reported. It is also whether the inclusion of the defamatory statement was justifiable. Also, the defamatory statement's public interest lay in the fact that it was made rather than its truth (reportage) and any other relevant circumstances. ${ }^{79}$ Even though that other cases may have other factors to be considered. Therefore, it may not be relevant in a social media context since it is "overemphasizing" factors based on journalistic practices. ${ }^{80}$

\section{New Zealand}

New Zealand decided to develop its form of qualified privilege rather than follow the Reynolds case. Based on Lange $v$ Atkinson protected statements made generally if they directly concerned the functioning of representative and responsible government, including Parliament members in their capacity to meet public responsibilities. ${ }^{81}$ In New Zealand's qualified privileged, the defense could be lost if the defendant was motivated by ill will or took improper advantage of the publication. ${ }^{82}$ that has to be proven by the plaintiff. New Zealand's approach to qualified privileged is narrow as it only protected political speech. However, it is wider than the Reynolds

78 Liu, supra note 52 at 9.

79 Grant, 126.

80 Dean Jobb, "Responsible Communication on Matters of Public Interest: A New Defense Updates Canada's Defamation Law” (2010) J Int'1 Media \& Entertainment Law 3 at 220.

81 Lange v Atkinson (1998) 3 NZLR 424 (CA) at 468.

${ }^{82}$ Liu, supra note 52 at 9. 
case, as it does not require consideration of responsible journalism except if questions related to malice arose. ${ }^{83}$

New Zealand also recognized public defense as a discrete defense instead of an extension of qualified privilege. This started with Durie v Gardiner. ${ }^{84}$ Sir Edward Durie and Donna Hall (the plaintiffs) issued defamation proceedings in the High Court against Māori TV and one of its reporters, Heta Gardiner (the defendants). The plaintiffs contended that Māori TV's broadcast contained various defamatory statements. They sought damages and a recommendation for publication of a correction. Mallon J believed that it was plausible for a public interest defense to be recognized in New Zealand in the High Court. This decision was appealed to the Court of Appeal, wherein a unanimous judgment, the Court of Appeal accepted that public interest defense for defamation was available in New Zealand for six reasons. First, there is more power residing outside of the political sphere, and there is increased public expectation in the accountability of nonpolitical groups. ${ }^{85}$ Second, there have been significant changes in mass communications due to new technologies. Third, the emergence of social media and the citizen journalist has changed the nature of public disclosure. Fourth, the New Zealand Bill of Rights Act (NZBORA), particularly the right to freedom of expression, has become more prominent. Fifth, the importance of juries in defamation trials has diminished. Sixth, the significance of other common law jurisdictions, such as the United Kingdom and Canada, has developed public interest defenses. ${ }^{86}$

Ibid at 10.

${ }^{84}$ Randall Stephenson, "Durie v Gardiner: Public Libel Law and Stare Non Decisis" (2020) Modern Law Review 83:3 at 637.

85 Ibid at 646.

${ }^{86}$ Awmee, supra note 45 at 14. 


\section{B. A Comparison to Indonesia's Concept of Public Interest Defense}

1. The Criminalization of Defamation

First, unlike the United Kingdom, Canada, New Zealand, and principally most common law countries, Indonesia recognizes defamation as a crime. The problem appeared when Indonesian laws do not have a well-defined definition and boundaries to defamation act. Indonesia also does not recognize a privileged concept that limits and gives a borderline to what actions are categorized as defamation. Given the nature of defamation cases in Indonesia, people tend to defy allegations through civil and criminal law. They are especially well-known parties and tend to increase their exposure by reporting the police's alleged defamation instead of only suing based on tort law. This happened to many people in Indonesia, such as Prita Mulyasari that Omni International Hospital reported, ${ }^{87}$ Jerinx SID that the Indonesian Doctor Association reported, ${ }^{88}$ and Richard Lee was reported by Kartika Putri. Therefore, defamation cases are increasing, and defamation seems to be over-criminalized. ${ }^{89}$

\section{The Blur of Public Interest Defense}

In the cases in the United Kingdom, Canada, and New Zealand, the courts' decision created a new public interest defense concept with its requirements. As a civil law country, Indonesia cannot rely on courts' decisions on various defamation cases. Public interest defense must be written down in law for it to be legally binding. If not, the media, especially social media, emerge a chilling effect and disturb the freedom of expression protected in the Indonesian constitution. Moreover, it also frightens people from publishing useful publications that might be helpful to others.

87 Lukman Hakim, "The Symptoms of Over-Criminalization on Defamation Through Electronic Media in Indonesia" (2019) South East Asia Journal of Contemporary Business, Economics and Law 19:5 at 67.

88 Arifin, supra note 11 at 25.

89 Hakim, supra note 69 at 73. 


\section{CONCLUSION}

In Indonesia, defamation law is specifically regulated in the Criminal Code and the ITE Law. Most defamation cases in Indonesia are referred to Articles 310 and 311 of the Criminal Code, while public interest defense is established in Article 310(3) of the Criminal Code. However, there are no specific requirements for public interest defense to have prevailed, thus it results in confusion in appearing new cases, like in the Richard Lee's case. By comparison, in other civil law countries, such as South Korea and Japan, Richard Lee's case may use public interest defense as it has fulfills the defense criteria. United Kingdom, Canada, and New Zealand's perspectives on public interest defense provide a better explanation on this issue. These countries consider public interest defense as a discrete defense applied if the defendant can prove the requirements. For legal certainty and to avoid overcriminalization of defamation, Indonesia should establish regulations to determine which act is categorized as protecting the public interest.

\section{ACKNOWLEDGMENTS}

None.

\section{COMPETING INTERESTS}

The author declared that she has no competing interests.

\section{REFERENCES}

Aceto, Bonner, and Cole PC, The five requisite elements of a defamation lawsuit? (2017), online: <http://www.acetolegal.com/Articles/Thefive-requisite-elements-of-a-defamation-lawsuit.shtml>.

Ahmad Sofian, Tafsir Pasal Pencemaran Nama Baik, online: <https:// business-law.binus.ac.id/2017/12/28/tafsir-pasal-pencemaran-namabaik/>. 
Anak Agung Saraswati, "The Need to Protect Freedom of Expression on the Internet through a Human Rights-Based in Indonesia" (2019) Asian Journal of Legal Studies 2/1.

Anggara, et. al., " Menimbang Ulang Pasal 27 ayat (3) UU ITE dalam Putusan Pengadilan: Pertimbangan Putusan Pengadilan Terkait Penggunaan Pasal 27 ayat (3) UU No 11 Tahun 2008 tentang Informasi dan Transaksi Elektronik di Indonesia" (2016) Institute for Criminal Justice Reform.

Baharudin Al Farisi, Alasan Kartika Putri Tetap Laporkan Richard Lee ke Polisi walau Sudah Minta Maaf, online: <https://www.kompas.com/ hype/read/2021/03/01/071730266/alasan-kartika-putri-tetaplaporkan-richard-lee-ke-polisi-walau-sudah-minta?page=all> .

Dean Jobb, "Responsible Communication on Matters of Public Interest: A New Defense Updates Canada's Defamation Law" (2010) J Int'l Media \& Entertainment Law 3.

Devesh Awmee, "With Great Power Comes Great Responsibility: An Analysis of the New Public Interest Defense to Defamation Claims" (2018) University of Wellington.

Dyah Rosiana Puspitasari, "Judicial Review of Criminal Defamation According to The Law of Electronic Information and Transaction: A Case Study of Flourence Saulina Sibombing" (2017) Yustisia 6/3.

Emily Howie, "Protecting the Human Right to Freedom of Expression in International Law" (2018) International Journal of Speech-Language Pathology 20/1.

Erwin Asmadi, "Rumusan Delik dan Pemidanaan Bagi Tindak Pidana Pencemaran Nama Baik di Media Sosial' (2021) Delegalata 6/1.

Eti Mul Erowati. "Compensation of defamation in Indonesia" (2019) 358 3rd International Conference on Globalization of Law and Local Wisdom (ICGLOW 2019).

Fifink Praiseda Alviolita and Barda Nawawi Arief, "Kebijakan Formulasi tentang Perumusan Tindak Pidana Pencemaran Nama Baik dalam Pembahar an Hukum Pidana di Indonesia" (2019) Law Reform 15/1. 
Judith Townend. "Freedom of Expression and the Chilling Effect" (2017) Routledge Companion to Media and Human Rights.

Jun Shimizu. "Defamation and Privacy Law in Japan - from a Comparative Perspective" (2020) Comparative Privacy and Defamation.

Kamshad Mohsin and Zainab Zaya Khan, "Right to Privacy in Digital Era" (2020) SSRN.

Kyung Sin Park and Jong-Sung You. "Criminal Prosecutions for Defamation and Insult in South Korea with a Leflarian Study in Election Contexts" (2017) University of Pennsylvania Asian Law Review 12:4.

Lukman Hakim, "The Symptoms of Over-Criminalization on Defamation Through Electronic Media in Indonesia" (2019) South East Asia Journal of Contemporary Business, Economics and Law 19/5.

M. Fauzi, "State, Public Interest, and Bankruptcy: The Case of Indonesia" (2018) South East Asia Journal of Contemporary Business, Economics, and Law 15/5.

Muhammad Ardiansyah Arifin, et al., "Indonesia Abuse of Defamation Clause in Article 27 Section (3) of Electronic Information and Transaction Law" (2020) South East Asia Journal of Contemporary Business, Economics and Law 23:1.

Nadiyah Munisah Hamelia, "The Implementation of the International Covenant on Civil and Political Right (ICCPR) as an International Regime in Indonesia During the Joko Widodo Era (2014-2019)" (2020) Mediasi: Journal of International Relation.

Nono Anwar Makarim, "Press Freedom in Indonesia: A Case of Draconian Laws, Statutory Misinterpretation, but still one of the Freest in Southeast Asia," (2010) Journal of Civil Law Studies 3/1.

Putra Akay, "Pasal 310 ayat (3) Kitab Undang-Undang Hukum Pidana Sebagai Suatu Alasan Penghapus Pidana Khusus" (2019) Lex Crimen $\mathrm{VIII} / 8$.

R. Herlambang Perdana Wiratraman, "New Media and Human Rights: The Legal Battle of Freedom of Expression in Indonesia" (2010) 
$11^{\text {th }}$ Annual Student Human Rights Law Conference Nottingham University.

R. Soesilo, Kitab Undang-Undang Hukum Pidana (KUHP) : Serta Komentar-Komentarnya Lengkap Pasal Demi Pasal, (Bogor: Politeia, 1996).

Rafika Nur, et al. "Insult and Defamation through Information Technology: Indonesia Perspective" (2020) International Journal of Emerging Technologies 11:4

Raisa L. Saroinsong, "Pertanggung Jawaban terhadap Pelaku Tindak Pidana Pencemaran Nama Baik Berdasarkan Pasal 310 KUHP" (2017) Lex Privatum V/7.

Randall Stephenson, "Durie v Gardiner: Public Libel Law and Stare Non Decisis” (2020) Modern Law Review 83:3

Reydi Vridell Awawangi, "Pencemaran Nama Baik dalam KUHP dan Menurut UU No 11 Tahun 2008 tentang Informasi dan Transaksi Eletronik" (2014) Lex Crimen III:4.

Rosa Agustina, Perbuatan Melawan Hukum, (Jakarta: Penerbit Pasca Sarjana FH Universitas Indonesia, 2003).

Ruiteng Liu, "Innovation and Reform: Applying New Zealand's Public Interest Defense in Defamation to Social Media and Blogs" (2020) Victoria University of Wellington Legal Research Papers 21/7.

S. R. Sianturi, Tindak Pidana di KUHP Berikut Uraiannya, (Jakarta: Alumni AHM-PTHM, 1983).

Satria Ardi Yana and Bambang Tri Bawono, "Effectiveness of Implementing EIT Laws and Investigations Damnation through Social Media" (2020) Law Development Journal 2/3.

Sitti Aisah Abdullah, et al. "The Legal Protection for Journalism of Citizen in the Spread Corona Virus Disease 2019 (COVID-19)" (2020) Scholars International Journal of Law, Crime and Justice.

Soerjono Soekanto and Sri Mamudji, Peranan dan Penggunaan Kepustakaan di dalam Penelitian Hukum, (Jakarta: Pusat Dokumentasi UI, 1979). 
266 | Our Right to Share, Their Right to Know: An Analysis of Public Interest Defense to Defamation

Sri Mamudji, et, al., Metode Penelitian dan Penulisan Hukum, (Jakarta: Badan Penerbit Fakultas Hukum Universitas Indonesia, 2005).

Tim, Tanggapan BPOM Terkait Perseteruan Richard Lee-Kartika Putri (2021) online: <https://www.cnnindonesia.com/gaya-hidup/2021020 8205046-277-603874/tanggapan-bpom-terkait-perseteruan-richardlee-kartika-putri>. 